\title{
ERCP maneuvers for situs inversus totalis
}

\author{
Mateus Pereira FUNARI, Igor Braga RIBEIRO, Bruno Salomão HIRSCH, \\ Marcos Eduardo Lera dos SANTOS and Eduardo Guimarães Hourneaux DE MOURA
}

Received: 3 December 2020 Accepted: 10 December 2020

Situs inversus totalis is a rare autosomal recessive congenital anomaly, with an estimated incidence of 1 case per 10,000 births $^{(1,2)}$. Endoscopic retrograde cholangiopancreatography (ERCP) is a challenging procedure in this condition ${ }^{(3-6)}$.

We present the case of a 55-year-old woman with a previous diagnosis of situs inversus totalis (FIGURE 1) and history of intraductal papillary mucinous neoplasm (IPMN) in the head of the pancreas who progressed to malignant degeneration and obstructive jaundice in July 2019. She was submitted to ERCP in an external service when the diagnosis was made and biliary drainage was performed for later palliative chemotherapy. In July 2020, the patient presented clinical worsening and jaundice (total bilirubin $=20 \mathrm{mg} / \mathrm{dL}$, predominantly direct hyperbilirubinemia), being referred for another ERCP.

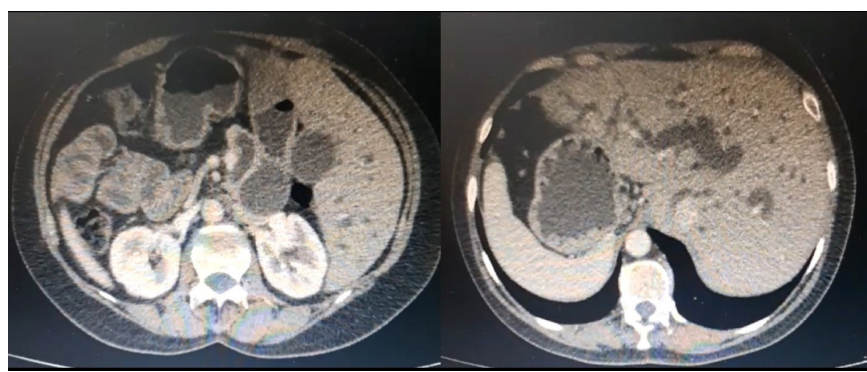

FIGURE 1. Computed tomography of the abdomen highlighting the altered anatomy in the patient with situs inversus totalis.

In this procedure, we highlight the technical difficulty, both initially and during the exam, as the endoscopist's movement is completely opposite to the usual (FIGURE 2), as well as the interpretation of the images in radioscopy (FIGURE 3) (E-VIDEO*).

The procedure was performed with the patient in ventral position. A tumor infiltration in the papilla was observed causing tissue retraction with friable mucosa. With surgical precision, the cannulation was performed in a single attempt, and after widening the previous biliary sphincterotomy there was an abundant
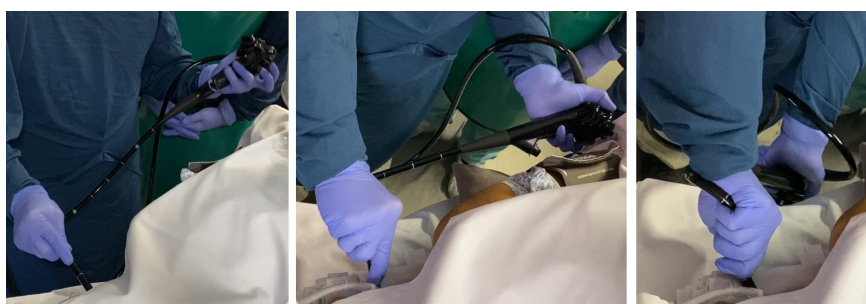

FIGURE 2. Due to anatomical changes, the endoscopic retrograde cholangiopancreatography (ERCP) maneuvers are completely reversed. The passage of the duodenoscope to the second duodenal portion is demonstrated.

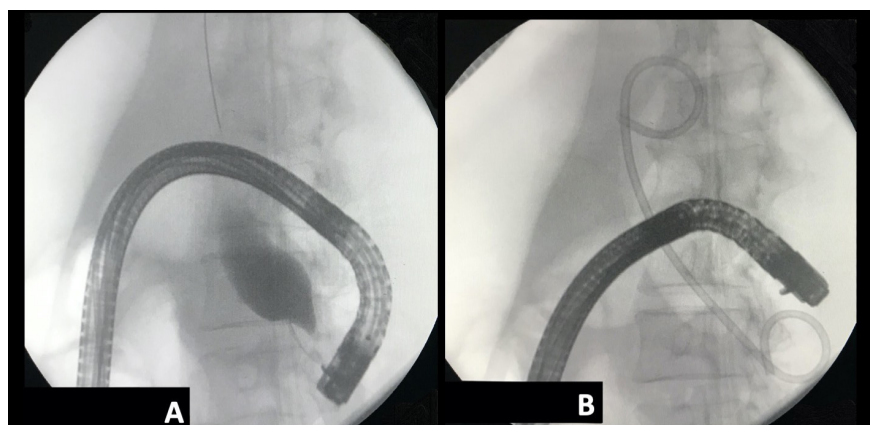

FIGURE 3. Radioscopy highlighting the altered anatomy in the patient with situs inversus totalis. A. Beginning of the procedure. B. Final aspect.

drainage of frankly purulent content demonstrating suppurative cholangitis. Then, a $10 \mathrm{Fr}$ x $6 \mathrm{~cm}$ double pigtail plastic biliary stent was placed, with good drainage of the purulent contents. The patient received antibiotics during the procedure and up to 7 days afterward.

She progressed well and was discharged 2 days after the procedure, with a drop in total bilirubin levels to $2.3 \mathrm{mg} / \mathrm{dL}$. Currently, she has an outpatient follow-up and is still under palliative chemotherapy.

Declared conflict of interest of all authors: none

Disclosure of funding: no funding received

Faculdade de Medicina da Universidade de São Paulo, Hospital das Clínicas, Unidade de Endoscopia Gastrointestinal São Paulo, SP, Brasil.

Corresponding author: Igor Braga Ribeiro. MD. E-mail: igorbraga1@gmail.com

*E-VIDEO: https://youtu.be/8Y68R_hTDrO 


\section{Authors' contribution}

Funari MP: study concept and design, acquisition of data, did the video editing. Ribeiro IB: performed the procedure, study concept and design, acquisition of data, data interpretation, critical revisions. Hirsch BS: assisted in editing the video, data interpretation, critical revisions. Santos MEL: data interpretation, critical revisions. de Moura EGH: data interpretation, critical revisions.

\section{Orcid}

Mateus Pereira Funari: 0000-0003-1183-9840.

Igor Braga Ribeiro: 0000-0003-1844-8973.

Bruno Salomão Hirsch: 0000-0002-0777-0150.

Marcos Eduardo Lera dos Santos: 0000-0001-9759-3807.

Eduardo Guimarães Hourneaux de Moura: 0000-00028023-3722.

Funari MP, Ribeiro IB, Hirsch BS, Santos MEL, de Moura EGH. Manobras para CPRE em pacientes com situs inversus totalis. Arq Gastroenterol. 2021:58(2):264-5.

\section{REFERENCES}

1. Varano NR, Merklin RJ. Situs inversus: review of the literature, report of four cases and analysis of the clinical implications. J Int Coll Surg. 1960;33:131-48.

2. Feng Q, Yao J. Hepatobiliary and Pancreatic: Common bile duct stones with situs inversus totalis. J Gastroenterol Hepatol. 2020;35:12.

3. Shimoda F, Satoh A, Asonuma S, Umemura K, Shimosegawa T. Successful removal of multiple bile duct stones using a papillary large balloon dilation in a very elderly woman with situs inversus totalis. Clin J Gastroenterol. 2021;14:309-13.

4. Mohandas S, Dickson-Lowe R, Karanjia N. Intraductal Papillary Mucinous Neoplasm (IPMN) of the Pancreas with Situs Inversus Totalis - Case Report with Review of Literature. J Gastrointest Cancer. 2012;43(S1):136-8.
5. Galetti F, Moura DTH de, Ribeiro IB, Funari MP, Coronel M, Sachde AH, et al. Cholangioscopy-guided lithotripsy vs. conventional therapy for complex bile duct stones: a systematic review and meta-analysis. ABCD Arq Bras Cir Dig. 2020;33:e1491.

6. Funari MP, Ribeiro IB, de Moura DTH, Bernardo WM, Brunaldi VO, Rezende DT, et al. Adverse events after biliary sphincterotomy: Does the electric current mode make a difference? A systematic review and meta-analysis of randomized controlled trials. Clin Res Hepatol Gastroenterol. 2020;44:739-52. 